\title{
Effect of Dry Red Grape Pomace as a Nitrite Substitute on the Microbiological and Physicochemical Properties and Residual Nitrite of Dry-cured Sausage
}

\author{
Fatemeh Riazi $^{1}{ }^{*}$, Fariba Zeynali ${ }^{1}$, Ebrahim Hoseini ${ }^{2}$, Homa Behmadi $^{3}$ \\ 1- Dept.of Food Science and Technology, Faculty of Agriculture, University of Urmia, Urmia, Iran \\ 2- Dept.of Food Science and Technology, Faculty of Food Science and Technology, Science and Research Branch, Islamic Azad University, Tehran, Iran \\ 3- Agricultural Engineering Research Institute, Food Engineering and Post-harvest Technology Res. Dept, Tehran, Iran
}

\section{A B S T R A C T}

Background and Objectives: Sodium nitrite and potassium nitrite have been traditionally used for inhibition of Clostridium botulinum and also as an agent to stabilize the color of meat products; however, usage of these additives at high levels could lead to toxicity and cancer originating from the formation of nitrosamines. Nowadays, application of natural preservatives in order to reduce the nitrite content in meat products is increasing. Thus, we used dry red grape pomace (DRGP) as a natural alternative to sodium nitrite.

Materials and Methods: The effect of two levels of DRGP (1 and 2\%) on the proximate composition, microbial counts, $\mathrm{pH}$ values and residual nitrite level of the samples formulated with two levels of sodium nitrite (30 and $60 \mathrm{mg} / \mathrm{kg}$ ), as well as the comparison of these sausages with the blank (nitrite-free) and control (full nitrite added) samples on the $1 \mathrm{rst}, 10^{\text {th }}, 20^{\text {th }}$ and $30^{\text {th }}$ days of storage at $3-5{ }^{\circ} \mathrm{C}$ were evaluated.

Results: The results showed that all chemical compositions were in the ranges reported by other researchers, and nitrite was very effective in preventing the microbial growth. Also about $50 \%$ of the ingoing nitrite could be analyzed in the samples after processing. Moreover, the residual nitrite level declined both during the storage of sausage and after the addition of DRGP.

Conclusions: The use of DRGP in combination with nitrite for sausages was more effective in keeping the quality and safety of the refrigerated consumer products as indicated by the lower nitrite levels, microbial count and similar composition as compared to the samples treated with nitrite and without nitrite.

Keywords: Dry red grape pomace (DRGP), Sausage, Nitrite, Microbial count

\section{Introduction}

Grape pomace, as a by-product, constitutes $25 \%$ of the grape weight whose seed is about $38-52 \%$ on dry basis (1). It is usually burned, causing environmental pollution or much of it is discarded without any type of treatment, causing great environmental impacts such as increasing biochemical and chemical oxygen demands (2). Grape pomace is a natural product rich in dietary fibers and polyphenols. Grape by-products have drawn increased attention in recent years for their potential health benefits. Flavanols are the most abundant phenolic compounds in grape peel and grape seeds, being rich in monomeric phenolic compounds (3). These compounds act as antimutagenic and antiviral agents; they can also be used to preserve food because of their protective effects against microorganisms (4). As sources of natural antioxidants, these substances could be reused as additive substitutes or new ingredients in the food and pharmaceutical industries $(5,6)$.

Nitrite is a well-known ingredient used as a curing agent in sausage, It is one of the most effective means of controlling pathogenic bacterial growth, mainly from Clostridium botulinum; however, in addition to 
acting as a strong antioxidant, it can significantly affect the color, odor and flavor of sausage (7).

During cooking, nitrite can combine with secondary amines and amino acids in meat products and form $\mathrm{N}$-nitroso compounds( e.g. nitrosamines) having health risks including allergic effects, vasodilator effects, metmyoglobin production, and production of carcinogenic nitrosamines (8). Recently, consumers have developed a stronger negative view towards artificial additives; therefore, the industry, researchers and official bodies are trying to respond to current consumer demands.

Meat and meat products are essential components in the human diets of the developed countries. Their consumption is affected by various factors such as paying attention to nutritional properties and safety. Many studies have been done about adding various plant materials instead of nitrite because of having effective antioxidant and antimicrobial properties. There has been some research dealing with a strategy for using natural ingredients/additives instead of nitrite in without/low added nitrite products to reproduce the functions (color, antioxidant activity, antimicrobial property, etc.) of nitrite like citrus fruits by-products (9), green tea (10), bearberry (11) grape seed (12) rosemary and oregano (13). The aim of this study was to determine the individual and cumulative effects of sodium nitrite and DRGP powder on the TBARS, color change and sensory evaluation of cooked sausages after 30 days of storage at $4^{\circ} \mathrm{C}$.

\section{Materials and Methods}

Preparation of grape pomace: The pomace (nitrite level: $3.2 \pm 1.2 \mu \mathrm{g} / \mathrm{ml}$ ) of the variety Vitis vinifera $\mathrm{L}$. var. Siahe Sardasht a by-product of red grape juice manufacturing process, was supplied by Azarkam Juicing Company (Urmia, Iran). The grape pomace studied was composed of stems, seeds and skins (without any separation of their components). The samples were dried in an industrial counter current dryer at $40-60^{\circ} \mathrm{C}$ for $6-12 \mathrm{~h}$, They were dehydrated to a moisture content of approximately $11.15 \%$, milled by a grinder and passed through a 60-mesh standard sieve to obtain a uniform particle size distribution. In order to eliminate all microbial contaminations, they were exposed to gamma irradiation at the dose of 25 kGy in the Atomic Energy Organization (Tehran,
Iran). They were stored at $4^{\circ} \mathrm{C}$ in a dark place for several weeks before use.

Sausage preparation: The sausages were manufactured according to a traditional formulation (Table 1) in the pilot plant of Solico Co. (Tehran, Iran). Five different formulations (all with 55\% meat) were studied. The control sample was prepared traditionally with chemical nitrite added $(120 \mathrm{mg} / \mathrm{kg}$ ), and the blank sample was prepared without any chemical nitrite added. The reformulated samples were prepared with different percentages of grape pomace $(1-2 \%)$ and nitrite $(30-60 \mathrm{mg} / \mathrm{kg})$. Materials including beef meat $(55 \%$ comprising moisture: $69.98 \% \pm 0.8$, protein: $19.08 \% \pm 0.4$, lipid: $9.97 \% \pm$ 0.4 , and ash: $0.79 \% \pm 0.01$ ), water (in the ice form $15.87 \%)$, sugar $(0.7 \%)$, soybean oil $(15.3 \%), \mathrm{NaCl}$ $(0.9 \%)$, starch (3\%), soybean isolate (3\%), $\mathrm{Na}_{5} \mathrm{P}_{3} \mathrm{O}_{10}$ $(0.3 \%)$, frozen garlic powder (1\%), ascorbic acid $(1.25 \%)$ and spice $(1.25 \%$, mixture of black pepper, mace, coriander, ginger and cardamom) were transferred to a chilled cutter (Seydelmann, Aalen, Germany), and the following preservatives (nitrite/grape pomace) were added in different levels to each treatment described in Table 1 in the pilot cutter. After complete homogenization, all samples were stuffed into $50 \mathrm{~mm}$-diameter polyamide casings, previously humidified with lukewarm water. The sausages were heat-processed for $1 \mathrm{~h}$ until the core of the product reached $75^{\circ} \mathrm{C}$. The internal temperature was monitored by using thermocouples (Omega Engineering, Inc. Stamford, CT) inserted in each sample (thermal center), and when heating was complete, the sausages were chilled in a cold water bath $\left(15^{\circ} \mathrm{C}\right)$ and stored at $4^{\circ} \mathrm{C}$ until further analysis for 30 days. All batches were produced in duplicate.

Table 1. DRGP (\%) and sodium nitrite $(\mathrm{mg} / \mathrm{kg})$ content of beef sausage

\begin{tabular}{ccc}
\hline Treatment & Sodium nitrite $(\mathrm{mg} / \mathrm{kg})$ & DRGP $(\%)$ \\
\hline Control & 120 & 0 \\
Blank & 0 & 0 \\
$\mathrm{~T}_{1}$ & 60 & 1 \\
$\mathrm{~T}_{2}$ & 30 & 1 \\
$\mathrm{~T}_{3}$ & 60 & 2 \\
$\mathrm{~T}_{4}$ & 30 & 2 \\
\hline
\end{tabular}

Chemical composition: Proximate analysis of the meat and sausage samples was conducted by the methods of AOAC (14). The results were expressed as moisture\%, protein $\%$, fat $\%$, ash $\%$ and 
carbohydrate\%. Feder value was calculated as the moisture/protein ratio according to Pearson (1981)(15).

Determination of $\mathbf{p H}$ : The $\mathrm{pH}$ of the raw sausage was determined using a pH-meter (Zagchemi, Iran) by direct measurement with a glass electrode calibrated with the phosphate buffers 4.0 and 7.0 at room temperature $\left(21^{\circ} \mathrm{C}\right)$ for all samples. The sample was blended and homogenized in distilled water at a ratio of 10:90 (w/v) for $2 \mathrm{~min}$, and its $\mathrm{pH}$ was measured (16).

Microbiological analysis: The microbiological characteristics of the samples were assessed on the days $0,10,20$ and 30 after manufacture, according to the methodology described by Viuda-Martos M et al. (2010) in triplicate. For each sample, $25 \mathrm{~g}$ was separated from the interior of the sausage with a sterile scalpel and forceps. They were then homogenized with $225 \mathrm{ml}$ of $0.1 \%$ peptone water in a Stomacher 400. Appropriate decimal dilutions were pour-plated on plate count agar for total viable count, and incubated at $35{ }^{\circ} \mathrm{C}$ for $48 \mathrm{~h}$. Psychrotrophic microbes were determined on Plate Count Agar, and the plates were incubated at $7{ }^{\circ} \mathrm{C}$ for 10 days (17).

Presumptive identification of Clostridium perfringens: For the identification of $C$. perfringens, the dilutions were poured into Sulfite Polymyxin Sulfadiazine Agar (SPS agar), placed in an anaerobic jar (BBL GasPak System, USA) with an anaerobic kit (Oxoid), and incubated at $37{ }^{\circ} \mathrm{C}$ for $48-72 \mathrm{~h}$. Microbial counts in this study were expressed as the logarithms of colony forming units (CFU) per gram of sample (Log cfu/g). All microbiological analyses were performed in duplicate (18).

Residual nitrite: Residual nitrite level (mg $\mathrm{NaNO}_{2} / \mathrm{kg}$ sample) was determined through the following standard ISO (2918). First, potassium ferrocyanide, zinc acetate, acetic acid and saturated borax solution were added to precipitate proteins. Then sulfanilamid, N-1 naphthyl ethylene diamine dihydro chloride and acid chloride were added to the filtrate, and red color was developed because of their interaction with nitrite. The absorbance value was measured at $538 \mathrm{~nm}$ using a UV-visible spectrophotometer (Unicam, Cambridge, UK)(19).

Statistical analysis: Data were analyzed using the SPSS software (ver. 15.0). Descriptive analysis was performed first in order to determine means \pm standard deviations of the three determinations of each parameter. Analysis of variance (one-way ANOVA) and Duncan`s multiple range test were carried out to evaluate the statistical significance $(p<0.05)$ of the effect of each formulation to establish statistical differences between the samples within each group. The analysis of the obtained data concerning the effects of time during the storage was carried out through the repeated measure analysis of variance (ANOVA). The data mean comparison was conducted the Bonferroni's multiple range test also in the probability level of 0.05 . All experiments were triplicated.

\section{Results}

The proximate analysis and the Feder values of the sausage samples are presented in Table 2. The results indicated that the control sample comprised $56.05 \%$ moisture, $14.65 \%$ protein, $21 \%$ lipid and $2.03 \%$ ash in the first day of storage. In the case of measured factors except for ash, no significant $(p>0.05)$ difference was observed between all the produced samples and the control one.

Table 2. Proximate analysis and Feder values of the sausage samples (on fresh weight basis)

\begin{tabular}{ccccccc}
\hline Treatment & Moisture & Protein & Carbohydrate & Fat & Ash & Feder value \\
\hline Control & $56.05^{\mathrm{A}} \pm 1.20$ & $14.65^{\mathrm{A}} \pm 0.77$ & $3.75^{\mathrm{A}} \pm 0.21$ & $21.00^{\mathrm{A}} \pm 1.27$ & $2.03^{\mathrm{C}} \pm 0.04$ & $3.83^{\mathrm{A}} \pm 0.28$ \\
Blank & $55.75^{\mathrm{A}} \pm 0.36$ & $15.10^{\mathrm{A}} \pm 0.56$ & $3.80^{\mathrm{A}} \pm 0.14$ & $21.45^{\mathrm{A}} \pm 0.35$ & $2.01^{\mathrm{C}} \pm 0.02$ & $3.69^{\mathrm{A}} \pm 0.11$ \\
$\mathrm{~T}_{1}$ & $56.31^{\mathrm{A}} \pm 0.01$ & $14.81^{\mathrm{A}} \pm 0.28$ & $3.82^{\mathrm{A}} \pm 0.10$ & $20.85^{\mathrm{A}} \pm 0.35$ & $2.23^{\mathrm{B}} \pm 0.04$ & $3.80^{\mathrm{A}} \pm 0.07$ \\
$\mathrm{~T}_{2}$ & $56.70^{\mathrm{A}} \pm 0.56$ & $14.85^{\mathrm{A}} \pm 0.49$ & $3.85^{\mathrm{A}} \pm 0.50$ & $20.65^{\mathrm{A}} \pm 0.49$ & $2.19^{\mathrm{B}} \pm 0.01$ & $3.81^{\mathrm{A}} \pm 0.08$ \\
$\mathrm{~T}_{3}$ & $57.25^{\mathrm{A}} \pm 1.35$ & $15.50^{\mathrm{A}} \pm 0.84$ & $4.37^{\mathrm{A}} \pm 0.49$ & $21.35^{\mathrm{A}} \pm 0.77$ & $2.41^{\mathrm{A}} \pm 0.02$ & $3.69^{\mathrm{A}} \pm 0.11$ \\
$\mathrm{~T}_{4}$ & $57.05^{\mathrm{A}} \pm 0.80$ & $15.45^{\mathrm{A}} \pm 0.91$ & $3.90^{\mathrm{A}} \pm 0.15$ & $20.80^{\mathrm{A}} \pm 1.69$ & $2.39^{\mathrm{A}} \pm 0.01$ & $3.69^{\mathrm{A}} \pm 0.23$
\end{tabular}

The same letters in each column show the non-significant difference in the probability level of 0.05 (p>0.05) in Duncan's test ( $\mathrm{n}=3$ replications) in oneway (ANOVA). Control and blank samples with 120 and $0 \mathrm{mg} / \mathrm{kg}$ nitrite, respectively, $\mathrm{T}_{1}(60 \mathrm{mg} / \mathrm{kg}$ nitrite, $1 \% \mathrm{DRGP}), \mathrm{T}_{2}(30 \mathrm{mg} / \mathrm{kg}$ nitrite, $1 \% \mathrm{DRGP})$, $\mathrm{T}_{3}(60 \mathrm{mg} / \mathrm{kg}$ nitrite, $2 \% \mathrm{DRGP}), \mathrm{T}_{4}(30 \mathrm{mg} / \mathrm{kg}$ nitrite, $2 \% \mathrm{DRGP})$. 
As observed in Table 3, as the nitrite level increased, the microbial load of the produced samples decreased significantly $(\mathrm{p}<0.05)$. In general, the population of the viable bacteria of the manufactured samples was less than that of the blank sample (Table $3)$. The effect of DRGP was not significant ( $>>0.05)$ for the produced samples. The microbial population followed an incremental trend significantly $(\mathrm{p}<0.05)$ in all samples during 30 days of storage. The blank sample had the highest microbial population on all days of storage as compared with the other samples. The obtained results revealed that all samples, except for the blank one, had a microbial population lower than the allowed limit at the end of storage. No C.perfringens was observed in any of the samples during storage, and the psychrotrophic bacteria were uncountable until the $30^{\text {th }}$ day of storage.
Addition of different amounts of DRGP created a significant $(\mathrm{p}<0.05)$ difference between the $\mathrm{pH}$ values of the DRGP-containing samples and those of the other samples (Figure 1). In the first day of storage, the $\mathrm{pH}$ values of all samples were in the range of 6.06.2. As observed, the $\mathrm{pH}$ values of all samples decreased gradually after 10 days of storage. They increased after 20 days of storage and even reached the values a little higher than the initial ones. The $\mathrm{pH}$ value of the blank sample was significantly $(p<0.05)$ higher than those of the other samples.

The residual nitrite increased with the rise in the nitrite level $(\mathrm{p}<0.05)$. Apart from the treatments, the residual nitrite level significantly $(\mathrm{p}<0.05)$ decreased gradually during storage (Figure 2), and as DRGP increased, the residual nitrite level decreased significantly $(\mathrm{p}<0.05)$.

Table 3. The effect of DRGP and nitrite on total viable counts (CFU/g) during chilling storage of raw cured sausages (on fresh weight basis) at the level of 0.05

\begin{tabular}{ccccc}
\hline \multicolumn{5}{c}{ Days of storage } \\
\hline & 1 & 10 & 20 & 30 \\
\hline Control & $2.672^{\mathrm{Ad}} \pm 0.021$ & $3.703^{\mathrm{Dc}} \pm 0.014$ & $4.152^{\mathrm{Db}} \pm 0.035$ & $4.491^{\mathrm{Da}} \pm 0.014$ \\
Blank & $2.671^{\mathrm{Ad}} \pm 0.026$ & $4.970^{\mathrm{Ac}} \pm 0.049$ & $5.446^{\mathrm{Ab}} \pm 0.035$ & $5.792^{\mathrm{Aa}} \pm 0.021$ \\
$\mathrm{~T}_{1}$ & $2.677^{\mathrm{Ad}} \pm 0.028$ & $3.910^{\mathrm{Cc}} \pm 0.021$ & $4.374^{\mathrm{Cb}} \pm 0.014$ & $4.716^{\mathrm{Ca}} \pm 0.028$ \\
$\mathrm{~T}_{2}$ & $2.658^{\mathrm{Ad}} \pm 0.021$ & $4.165^{\mathrm{Bc}} \pm 0.021$ & $4.633^{\mathrm{Bb}} \pm 0.035$ & $4.977^{\mathrm{Ba}} \pm 0.035$ \\
$\mathrm{~T}_{3}$ & $2.653^{\mathrm{Ad}} \pm 0.012$ & $3.902^{\mathrm{Cc}} \pm 0.028$ & $4.364^{\mathrm{Cb}} \pm 0.028$ & $4.702^{\mathrm{Ca}} \pm 0.021$ \\
$\mathrm{~T}_{4}$ & $2.644^{\mathrm{Ad}} \pm 0.002$ & $4.152^{\mathrm{Bc}} \pm 0.028$ & $4.619^{\mathrm{Bb}} \pm 0.014$ & $4.940^{\mathrm{Ea}} \pm 0.036$ \\
\hline
\end{tabular}

The same capital letter indicates no significant statistical difference in each column is at $5 \%$.

The same small letter indicates no significant statistical difference in each row at 5\%.

The numbers are the average of three replicates, and were reported as Mean \pm Standard Deviation. Control and blank samples with 120 and $0 \mathrm{mg} / \mathrm{kg}$ nitrite, respectively, $\mathrm{T}_{1}(60 \mathrm{mg} / \mathrm{kg}$ nitrite, $1 \% \mathrm{DRGP}), \mathrm{T}_{2}(30 \mathrm{mg} / \mathrm{kg}$ nitrite, $1 \% \mathrm{DRGP}), \mathrm{T}_{3}(60 \mathrm{mg} / \mathrm{kg}$ nitrite, $2 \% \mathrm{DRGP}), \mathrm{T}_{4}(30 \mathrm{mg} / \mathrm{kg}$ nitrite, $2 \% \mathrm{DRGP})$.

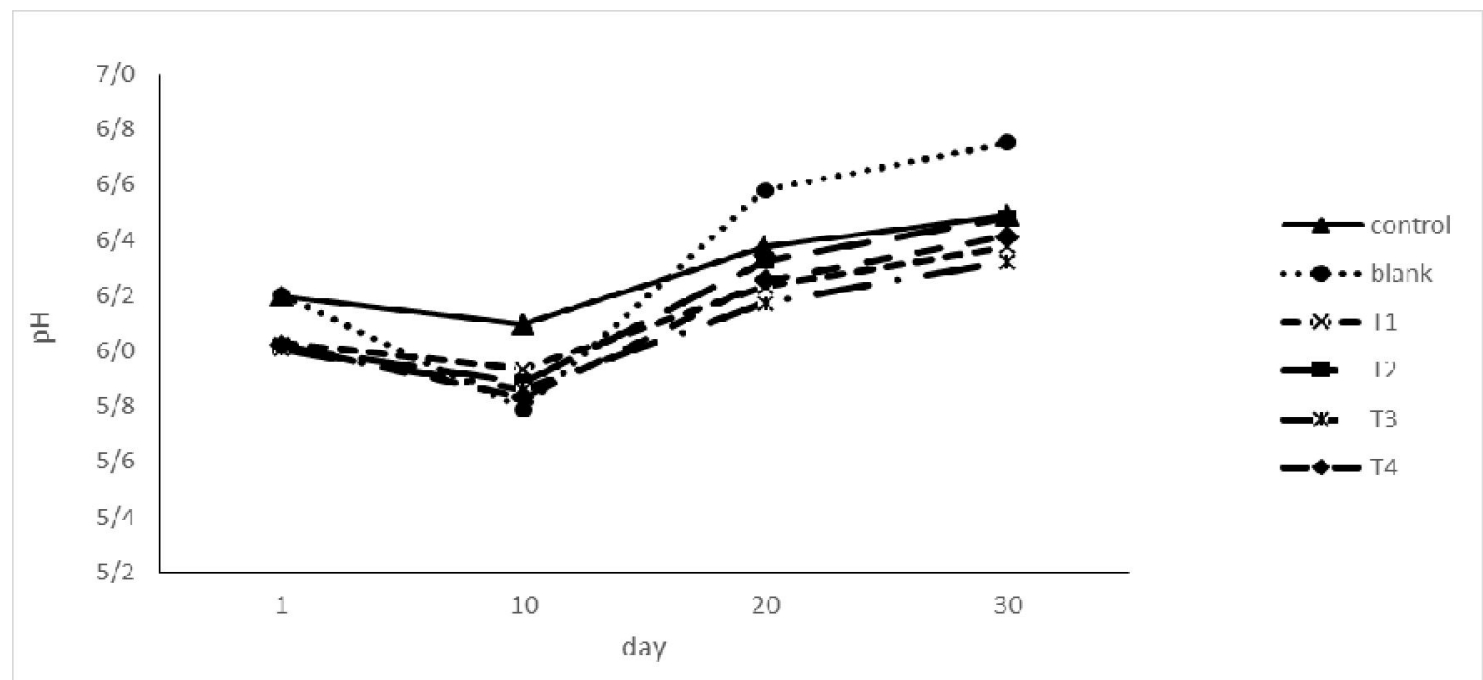

Fig. 1. $\mathrm{pH}$ value changes during chilling storage of raw cured sausages (on fresh weight basis) at the level of 0.05 .

Control and blank samples with 120 and $0 \mathrm{mg} / \mathrm{kg}$ nitrite, respectively, $\mathrm{T}_{1}(60 \mathrm{mg} / \mathrm{kg}$ nitrite, $1 \% \mathrm{DRGP}), \mathrm{T}_{2}(30 \mathrm{mg} / \mathrm{kg}$ nitrite, $1 \% \mathrm{DRGP}), \mathrm{T}_{3}(60 \mathrm{mg} / \mathrm{kg}$ nitrite, $2 \%$ DRGP), $\mathrm{T}_{4}(30 \mathrm{mg} / \mathrm{kg}$ nitrite, $2 \% \mathrm{DRGP})$. 


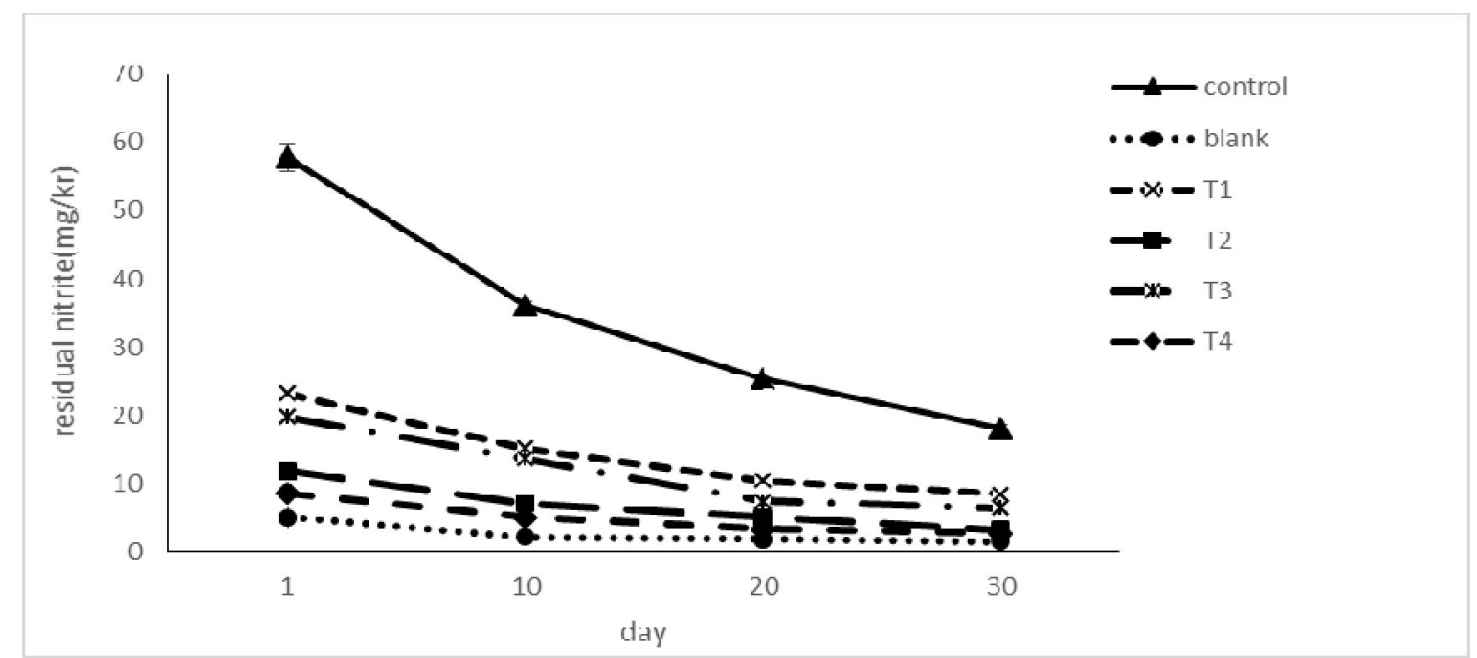

Fig. 2. Residual nitrite level (ppm) during the chilling storage of raw cured sausages (on fresh weight basis) at the level of 0.05 .

Control and blank samples with 120 and $0 \mathrm{mg} / \mathrm{kg}$ nitrite, respectively, $\mathrm{T}_{1}(60 \mathrm{mg} / \mathrm{kg}$ nitrite, $1 \% \mathrm{DRGP}), \mathrm{T}_{2}(30 \mathrm{mg} / \mathrm{kg}$ nitrite, $1 \% \mathrm{DRGP})$, $\mathrm{T}_{3}(60 \mathrm{mg} / \mathrm{kg}$ nitrite, $2 \% \mathrm{DRGP}), \mathrm{T}_{4}(30 \mathrm{mg} / \mathrm{kg}$ nitrite, $2 \% \mathrm{DRGP})$.

\section{Disc ussion}

Regarding the chemical analysis, Pereira et al. (2000) reported that most sausage formulas fall within the following specification: moisture $50-70 \%$, protein $11-15 \%$, fat $15-30 \%$, and ash contents $1.5-2.8 \%$ (on fresh weight basis). In the present research, the sausage samples' compositions were in the expected range (Table 2) (20).

Some special microbial species, causing the contamination of meat and meat products through environment, are considered as the microbial spoilage index during storage which are investigated in this study $(21,22)$. The antimicrobial power of nitrite reduced the microbial load of the manufactured samples. The remarkable effect of nitrite and DRGP was observed in reducing the number of aerobic bacteria. DRGP and herbal fibers have lower antimicrobial effect than herbal essential oils and extracts (23). Viuda-Martos et al. (2010) ascribed the antimicrobial activity of orange dietary fiber in sausage to its bioactive compounds, especially polyphenols and terpenes (22). The blank sample had the largest microbial population than the other samples due to the absence of preservatives. According to Iranian National Standard (No. 2303), the maximum microbial load is equal to $5 \log _{10} \mathrm{cfu} / \mathrm{g}$ (24). Since the $\mathrm{pH}$ value was adjusted to 6 , the cooking conditions were appropriate and the samples were carefully stored at $4^{\circ} \mathrm{C}$, the produced samples did not spoil during the 30 days of storage. However, as observed in Figure 1, as the $\mathrm{pH}$ value was elevated, the microbial population increased too, which was much more pronounced, particularly on the $30^{\text {th }}$ day. There is a close relationship between the $\mathrm{pH}$ value and the total microbial population. $\mathrm{pH}$ is one of the effective internal factors on microbial growth (25). Owing to its low $\mathrm{pH}$ (3.81), DRGP reduced the $\mathrm{pH}$ values of the samples, thus inhibiting the microbial growth to some extent via $\mathrm{pH}$ reduction. The antimicrobial activity of DRGP was not observed likely because of its low levels. C.perfringens was not observed, probably due to the low microbial population of the raw meat, cooking conditions and proper storage. Psychrotrophic bacteria that are able to grow at $7^{\circ} \mathrm{C}$ are the most important bacterial group in the putrefaction of meat products. Nevertheless, due to the predominance of gram-negative bacteria in this group and the more pronounced effect of the cooking temperature (pasteurization) on gramnegative bacteria, in addition to decrease in the thermal resistance of microorganisms by compounds such as phosphate and glutamate present in the formulation, the psychrotrophic bacteria were not countable during the storage time. The results of the present study conform to those of Viuda-Martos et al. 
(2010) who worked on the effects of orange fiber, oregano essential oil and rosemary essential oil on Mortadella sausage during storage at $4^{\circ} \mathrm{C}$. In that study, thermal processing, aseptic cutting, and the occurrence of salt in the product were also stated as the reasons behind the growth inhibition of psychrotrophic bacteria during storage (24 days) (17).

The reason for reduction in the $\mathrm{pH}$ values of the DRGP-containing samples is associated with the $\mathrm{pH}$ value of DRGP (3.81), and the low pH of DRGP is possibly because of the presence of organic acids and other acidic compounds in grape, and consequently, in its pomace (26). The $\mathrm{pH}$ reduction during the first 10 days of storage was caused by the lactic acid resulted from the metabolism of meat as well as the sugar present in the formulation by microorganisms $(22,27)$. Viuda-Martos et al. (2010) attributed the $\mathrm{pH}$ reduction to the production of lactic acid by lactic acid bacteria (22). The increase in $\mathrm{pH}$ value on the $20^{\text {th }}$ and $30^{\text {th }}$ days was probably due to the production of compounds such as ammonia resulted from the activity of microorganisms, in addition to the denaturation of proteins and accumulation of the raw materials $(28,29)$. As shown in Table 3 , as the number of the microorganisms increases, the $\mathrm{pH}$ value increases on the $20^{\text {th }}$ and $30^{\text {th }}$ days, which could be brought about by the production of secondary metabolites. This conclusion could be justified considering its large microbial population. With a gradual rise in the $\mathrm{pH}$ values of the samples, all samples showed $\mathrm{pH}$ values lower than the critical limit $(\mathrm{pH}=7)$ determined for sausage during the chilling storage (15). This could be because of the ability of nitrite and DRGP to reduce and inhibit the growth of microorganisms, and hence, reducing spoilage $(18,30)$. Nitrite is changed into nitrite oxide in meat, where it combines with myoglobin and creates the pink pigment of nitrosomyoglobin. This pigment is the reason behind the pink color of cured meats. The preliminary reduction of nitrite could be ascribed to the fact that only $50 \%$ of the added nitrite can be detected as sodium nitrite in the product. The majority of nitrite, which has changed into nitric oxide, is combined with myoglobin (5-15\%), sulfhydryl groups (5-15\%), lipids (1-5\%) and proteins (20-30\%), and only a minority of nitrite remains in the form of nitrate $(<10 \%)$ and nitrite $(10-15 \%)(31)$.
As a result, less than $50 \%$ of the added amount can be chemically analyzed after processing (32). The decrease in the nitrite content during storage may be associated with the dynamic deformation of nitrogen compounds in the muscle matrix (33). The content of the remaining nitrite decreased gradually during the first 10 days of storage, which was then bottomed out. After 20 days, all samples reached a bottom with a relatively constant ratio (i.e. there was not a large difference between the nitrite level of the $20^{\text {th }}$ and $30^{\text {th }}$ days) $(16,34)$.

The reduction in nitrite level during storage depends on different factors, including type of the raw meat, $\mathrm{pH}$, initial nitrite level, manufacture and storage temperature, and presence of the reducing factors (35). The concentration of the added nitrite has dramatic effect; the higher the nitrite level, the higher the remaining nitrite content (36). The high reactivity of nitrite enables it to react with bioactive compounds (DRGP polyphenols) (37). Some polyphenolic compounds show a strong protection against the nitrite ion, and prevent from the formation of nitrosamine (38). The reduction in the residual nitrite level and its reaction with the polyphenols occurred in DRGP led to a decreased formation of $\mathrm{N}$-nitroso compounds, which are very carcinogenic and mutagen (17). These results are similar to those obtained in the study by Fernández-Ginés et al. (2004) where the residual nitrite level of Bologna sausage reduced significantly through the addition of lemon albedo (39), and in the study ofViuda-Martos et al. (2010) where the addition of orange fiber and the essential oils of spices led to the reduction in the residual nitrite level of Mortadella (17). It also seems that besides the phenolic compounds, the decrease in nitrite was due to the low $\mathrm{pH}$ of the DRGP-containing samples because $\mathrm{pH}$ is one of the influential factors on the residual nitrite level. The residual nitrite level was acceptable and less than the critical limit of 100 ppm.

Addition of DRGP to sausage inhibited the microbial growth during 30 days of refrigeration storage, decreased residual nitrite level and $\mathrm{pH}$, and increased the shelf life of the sausage. Moreover, addition of DRGP to the meat product enhanced health-promoting properties and improved the stability of the produced samples. Due to the concerns 
regarding the safety and toxicity of nitrite, DRGP may be proved to be useful as a safe, natural, and health-promoting nitrite substitute in the meat industry.

\section{Acknowledgement}

The authors are grateful to the Solico Meat Products Factory(Tehran-Iran) for their assistance in carrying out the industrial conditions of the research.

\section{Financial disclosure}

The authors declared no financial interest.

\section{Funding/Support}

The study did not receive any financial support.

\section{References}

1. Maier T, Schieber A, Kammerer DR, Carle R. Residues of grape (Vitis vinifera L.) seed oil production as a valuable source of phenolic antioxidants. Food Chem 2009;112(3): 551-559.

2. Lafka T I, Sinanoglou V \& Lazos E S. On the extraction and antioxidant activity of phenolic compounds from winery wastes. Food Chem 2007;104(3): 1206-1214.

3. Kammerer D, Claus A, Carle R \& Schieber A. Polyphenol screening of pomace from red and white grape varieties (Vitis vinifera L.) by HPLC-DADMS/MS. J Agric Food Chem 2004; 52(14): 4360-4367.

4. Vattem D, Lin YT, Labbe R \& Shetty K. Antimicrobial activity against select food-borne pathogens by phenolic antioxidants enriched in cranberry pomace by solid-state bioprocessing using the food grade fungus Rhizopus oligosporus. Process Biochem 2004; 39(12): 1939-1946.

5. Denny C, Lazarini J, Franchin M, Melo P, et al. Bioprospection of Petit Verdot grape pomace as a source of anti-inflammatory compounds. J Funct Foods 2014; 8: 292-300.

6. Makris DP, Boskou G \& Andrikopoulos N K. Polyphenolic content and in vitro antioxidant characteristics of wine industry and other agri-food solid waste extracts. J Food Comp Anal 2007; 20(2): 125-132.

7. Cassens RG. Composition and safety of cured meats in the USA. Food Chem1997; 59(4): 561-566.

8. Jin S K, Kim Y J, Park J H, Hur I C, et al. Effects of purple-fleshed sweet potato (Ipomoera batatas Cultivar Ayamurasaki) powder addition on color and texture properties and sensory characteristics of cooked pork sausages during storage. Asian-Australa J Anim Sci 2012; 25(9): 1329

9. Fernández-López J, Fernández-Ginés J, AlesonCarbonell L, Sendra E, et al. Application of functional citrus by-products to meat products. Trends Food Sci Techno 2004; 15(3): 176-185.
10. Bozkurt H. Utilization of natural antioxidants: Green tea extract and Thymbra spicata oil in Turkish dryfermented sausage. Meat Sci 2006; 73(3): 442-450.

11. O'Grady M, Carpenter R, Lynch P, O'Brien N, et al. Addition of grape seed extract and bearberry to porcine diets: Influence on quality attributes of raw and cooked pork. Meat Sci 2008; 78(4): 438-446.

12. Brannan R. Effect of grape seed extract on descriptive sensory analysis of ground chicken during refrigerated storage. Meat Sci 2009;81(4): 589-595.

13. Hernández-Hernández E, Ponce-Alquicira E, JaramilloFlores M \& Legarreta I G. Antioxidant effect rosemary (Rosmarinus officinalis L) and oregano (Origanum vulgare L) extracts on TBARS and colour of model raw pork batters. Meat Sci 2009; 81(2): 410-417.

14. AOAC. 1995. Official Methods of Analysis (16th Ed.), Association of Official Analytical Chemists Arlington, Virginia, USA.

15. Pearson D. The chemical analysis of foods. 1976: Longman Group Ltd.

16. Fernández-López J, Viuda-Martos M, Sendra E, SayasBarberá E, et al. Orange fibre as potential functional ingredient for dry-cured sausages. Eur Food Res Technol 2007; 226(1-2): 1-6.

17. Viuda-Martos M, Ruiz-Navajas Y, Fernández-López J \& Pérez-Álvarez J. Effect of added citrus fibre and spice essential oils on quality characteristics and shelflife of mortadella. Meat Sci 2010; 85(3): 568-576.

18. Yetim H, Kayacier A, Kesmen Z \& Sagdic O. The effects of nitrite on the survival of Clostridium sporogenes and the autoxidation properties of the Kavurma. Meat Sci 2006; 72(2): 206-210.

19. ISO.1975. ISO No. 2918/75, 09-01. "Meat and meat products. Determination of nitrite 392 content" Switzerland: International Organization for Standardization.

20. Pereira N R, Tarley C R, Matsushita M \& Souza N E de. Proximate composition and fatty acid profile in Brazilian poultry sausages. J Food Compo Anal 2000; 13(6): 915-920.

21. Tajik H, Farhangfar A, Moradi M \& Razavi Rohani S.M. Effectiveness of clove essential oil and grape seed extract combination on microbial and lipid oxidation characteristics of raw buffalo patty during storage at abuse refrigeration temperature. J Food Process Preserv 2014; 38(1): 31-38.

22. Viuda-Martos M, Ruiz-Navajas Y, Fernández-López J \& Pérez-Álvarez J. Effect of orange dietary fibre, oregano essential oil and packaging conditions on shelflife of bologna sausages. Food Contr 2010; 21(4): 436443.

23. Riazi F, Zeynali F, Hoseini E, and Behmadi H, Determination of the Minimum Inhibitory 
Concentration of the Barberry Extract and the Dried Residue of Red Grape and Their Effects on the Growth Inhibition of Sausage Bacteria by Using Response Surface Methodology (RSM). Nutr Food Sci Res 2015; 2(4): 55-63.

24. ISIRI (2000). Meat \& meat products-sausages: specifications and method, 2303. Institute of Standards and Industrial Research of Iran.

25. Jay J M, Loessner M J \& Golden D.A. Modern food microbiology 2005: Springer.

26. Kyeong Seon Ryu K S S \& Shin D. Effect of Grape Pomace Powder Addition on TBARS and Color of Cooked Pork Sausages during Storage. Korean J Food Sci An 2014; 34(2): 200-206.

27. Viuda-Martos M, Ruiz-Navajas Y, Fernández-López J \& Pérez-Álvarez J. Effect of adding citrus waste water, thyme and oregano essential oil on the chemical, physical and sensory characteristics of a bologna sausage. Inno Food Sci Emerg Technol 2009; 10(4): 655-660.

28. Davies A R \& Board R G. Microbiology of Meat and Poultry 1998: Springer.

29. Kemp J D, Langlois B, Fox J \& Varney W. Effects of curing ingredients and holding times and temperatures on organoleptic and microbiological properties of dry-cured sliced ham. J Food Sci 1975; 40(3): 634-636.

30. Wójciak K M, Dolatowski Z J \& Okoń A. The effect of water plant extracts addition on the oxidative stability of meat products. Acta Sci Pol Technol Aliment 2011; 10(2): $175-188$

31. Ferreira I \& Silva S. Quantification of residual nitrite and nitrate in ham by reverse-phase high performance liquid chromatography/diode array detector. Talanta 2008; 74(5): 1598-1602.
32. Cassens R G, Woolford G, Lee S H \& Goutefongea R Fate of Nitrite in Meat Proceedings in 2nd International Symposium of Nitrite in Meat Products. 1976: Zeist, Pudoc, Wageningen, Netherlands.

33. De Mey E, Klerck K De, Maere H De, Dewulf L, et al. The occurrence of $\mathrm{N}$-nitrosamines, residual nitrite and biogenic amines in commercial dry fermented sausages and evaluation of their occasional relation. Meat Sci 2014; 96(2): 821-828.

34. Cassens R G. Use of sodium nitrite in cured meats today. Food Technol 1995; 49(7): 72-80.

35. Honikel K O. The use and control of nitrate and nitrite for the processing of meat products. Meat Sci 2008; 78(1): 68-76.

36. Cammack R, Joannou C, Cui X Y, Martinez C Torres, et al. Nitrite and nitrosyl compounds in food preservation. Biochimica et Biophysica Acta (BBA)Bioenergetics 1999; 1411(2): 475-488.

37. Fernández-López J, Sendra E, Sayas-Barberá E Navarro C, et al. Physico-chemical and microbiological profiles of "salchichón"(Spanish dry-fermented sausage) enriched with orange fiber. Meat Sci 2008; 80(2): 410-417.

38. Garrote G, Cruz J, Moure A, Dominguez H, et al. Antioxidant activity of byproducts from the hydrolytic processing of selected lignocellulosic materials. Trends Food Sci Techno 2004; 15(3): 191-200.

39. Fernández-Ginés J, Fernández-López J, Sayas-Barbera E, Sendra E, et al. Lemon albedo as a new source of dietary fiber: Application to bologna sausages. Meat Sci 2004; 67(1): 7-13. 1.

40. Maier T, Schieber A, Kammerer DR, R Carle R. Residues of grape (Vitis vinifera L.) seed oil production as a valuable source of phenolic antioxidants. Food Chem 2009;112(3): 551-559. 